\title{
Research on the Relationship among Internal Audit Quality, Interactive Mechanism of Management Structure and Corporate Value ${ }^{1}$
}

\author{
Huishui Su, Kaiyan Zheng, Sineng Li \\ Fujian Jiangxia University,Fujian Fuzhou,350108, China; Fujian Jiangxia University,Fujian \\ fuzhou,350108, China; Fujian Administration College,Fujian Fuzhou 35002
}

Keywords: internal audit; internal audit quality; corporate value; management structure

\begin{abstract}
From the perspective of internal audit, the paper makes an empirical analysis on the relationship among internal audit quality, interactive mechanism of management structure and corporate value by drawing the experience and statistics from listed companies in the year of 2012-2016. The result manifests that the internal audit quality, evaluated by the elements like independence, regulation, profession, company size and so on, is positively related to corporate value. In addition, a favorable interaction of management structure, such as chairman or CEO, can positively adjust enterprise worth. It turns out that the more attention it pays to internal audit quality, the higher value will add to the company.
\end{abstract}

\section{Introduction}

Ever since 1997 when Asian economic crisis, global financial crisis and vicious corporate financial scandals overwhelmed the world, a wave of research on internal audit has swept both practical and academic field. In 1999, IIA first stated clearly that internal auditing is an assurance and consulting activity designed to add value. In 2013, the Rules of Internal Design in China explicitly raised that internal auditing helps to improve corporate management structure and add the value. As the business environment changed, internal audit shifted from traditional financial audit to managerial audit, managed audit and risk-oriented audit, meaning an expansion of function from oversight and evaluation to assurance and consulting, even to more management fields. Thus, consulting arose to meet the needs of adding the value to the organization ${ }^{[1]}$.

Given the fact, this paper, from the research view of internal audit, makes an analysis on the relationship among internal audit quality, interactive mechanism of management structure and corporate value, shedding a light on how to increase corporate value.

\section{Literature Review and Research Hypothesis}

To a certain extent, internal audit quality comprehensively reflects company's internal control and audit level. Methods, like reinforcing audit ability, enhancing internal control capacity, improving

\footnotetext{
${ }^{1}$ Funded by: Internal Control, Corporate Management and the Management Performance of State-owned Listed Company (2014JDZ036), the key project of Fujian Social Science Planning; Research on the Performance Assessment Index of County-level Government under the Guidance of the Modernization of State Governance (2014B103), Fujian Social Science Planning Project; The Role and Methods of National Audit in State Governance (JA12335S), Social Science Project of the Education Department of Fujian Province.
} 
risk management competence and so on, are beneficial to improve internal audit quality and promote enterprise performance. However, internal audit quality is a systematic result of comprehensive effect of various elements. It is related to the independence of internal audit, the competence of the auditors, the size of internal auditing departments, share concentration (Chun Cai, etc., 2011) ${ }^{[2]}$, the choice of four big accounting firms (namely, PWC, DTT, KPMG, EY), the interaction of corporate governance system, etc. ${ }^{[3]}$ Based on this, this paper sets forth Hypothesis H1 to be tested.

Hypothesis H1: The high-quality internal audit helps to improve corporate performance and add the value.

The Rules of Internal Design of new revision in 2013 stated explicitly that internal auditing plays a governance role to add corporate value via assurance and consulting service. IIA Standards for the Professional Practice of Internal Auditing put forward that internal auditing is an independent, objective assurance and consulting activity designed to add value. For one thing, if senior management staffs give more support to internal audit (Singh, 2010) ${ }^{[4]}$, then audit will be more likely to work at full capacity to supervise and assess the performance of the organization. For another, the feedback of the audit could be a deterrent to the managers, so that they will be prompted to improve the management, which will add value to the organization indirectly. Based on this, this paper sets forth Hypothesis $\mathrm{H} 2$ to be tested.

Hypothesis H2: More improvements to the management structure contribute to more play of the oversight function of internal audit and more value added to the corporate.

This paper is based on the special projects and questionnaire survey on the listed companies in 2007 and 2014 and selects data from the listed companies that have relatively better disclosure of internal audit information during 2012-2016. Other data source comes from China Audit Yearbook, China Statistical Yearbook for Regional Economy, CSMAR, etc. The data processing screens out the samples from enterprise in financial sector, companies that miss the variable, and ST companies. The data with a variable level beyond $1 \%$ is accomplished with regression analysis by statistical software.

1. Explained variable. It is based on the research experience in academic field. Tobin's Q is chosen to measure corporate value.

2. Explanatory variable. On the basis of the researches by Chun Cai, etc. (2011), Bing Wang(2015), this paper chooses several elements as the explanatory variables, including the independence of internal audit, regulation of the system, culture and education background, professional competence and company size.

3. Intervening variable. With a reference to the researches by Shiying Huang, etc. (2014), Ying Chen(2016), this paper focuses on the attitude of chairman and CEO towards internal audit department.

4. Control variable. The measurement methods in most document materials enlighten this paper to select the following control variables: external audit quality, company size, capital structure, growth, return on assets, share concentration, board size, etc.

5. Dummy variable. Industry and year.

The following model is established to test whether internal audit quality helps to add corporate 
value.

$\mathrm{TQ}_{\mathrm{T}}=\alpha_{1}+\beta_{1} \mathrm{IA}_{\mathrm{T}}+\beta_{2} \mathrm{Lev}_{\mathrm{T}}+\beta_{3}$ Lnsize $_{\mathrm{T}}+\beta_{4}$ Growth $_{\mathrm{T}}+\beta_{5}$ Roa $_{\mathrm{T}}+\beta_{6}$ Share $_{\mathrm{T}}+$

$$
\beta_{7} \text { BoardSize }_{\mathrm{T}}+\beta_{8} \text { Big } 4_{\mathrm{T}}+\text { Year+Industry }+\xi_{\mathrm{T}} \quad \text { Model } 1
$$

In this model, principal components analysis is used to combine the explanatory variables into an index that comprehensively assesses internal audit quality (IA). A larger index reveals higher quality of internal audit.

Model 2 is established to test the attitude of management structure, like chairman and CEO, towards internal audit quality. The data is divided into two groups according to the value. And in the sample, internal audit quality and attitude of management structure are interchanged.

$$
\begin{gathered}
\mathrm{TQ}_{\mathrm{T}}=\alpha_{2}+\delta_{1} \mathrm{IA}_{\mathrm{T}}+\delta_{2} \text { ChairAtt }(\text { CEOAtt })+\delta_{3} \text { ChairAtt*IA } \quad(\text { CEOAtt*IA }) \\
+\delta_{4} \text { Lnsize }_{\mathrm{T}}+\delta_{5} \mathrm{Lev}_{\mathrm{T}}+\delta_{6} \text { Growth }_{\mathrm{T}}+\delta_{7} \mathrm{Roa}_{\mathrm{T}}+\delta_{8} \text { Share }_{\mathrm{T}}+\delta_{9} \text { BoardSize }_{\mathrm{T}}+\delta_{10} \text { Big }_{\mathrm{T}}+\text { Year+Industr } \\
\mathrm{y}+\xi_{\mathrm{T}} \\
\text { Model } 2
\end{gathered}
$$

\section{The Analysis of Empirical Result}

The analysis tells that the standard deviation is 0.823 while mean is 1.526 . It reveals that for the listed companies in China, the corporate value is not very high and there is a relatively large gap. The mean of internal audit department under the leadership of board is $79.2 \%$. $13.2 \%$ internal auditors got a CPA certificate while $79.3 \%$ received bachelor's degree or beyond. Generally there are about 4 staffs and $82.5 \%$ companies have relatively strict and complete internal audit system. It demonstrates that the internal audit system of listed companies becomes more and more standard after the special regulation of China Securities Regulatory Commission. However, as a whole, a great difference of internal audit quality still exists in the listed companies, with a standard deviation as high as 1.321 .

1. The testing of Hypothesis H1. The analysis of table 1 indicates that 5 indexes of internal audit quality are positively related to corporate value (TQ). With an exception of the independence, internal audit quality has an obvious positive correlation with corporate value. In the meantime, an empirical regression is made between corporate value and the comprehensive index of internal audit quality after principal components analysis, as shown in column TQ(6). The result tells that the coefficient of IA is a positive number under significance level of 0.01 . It suggests that higher internal audit quality devotes to higher corporate value, which serves as the proof of Hypothesis H1. 
Table 1 Multivariable Regression Analysis of Internal Audit Quality and Corporate Value

\begin{tabular}{|c|c|c|c|c|c|c|}
\hline Variables & $\mathrm{TQ}(1)$ & $\mathrm{TQ}(2)$ & TQ(3) & $\mathrm{TQ}(4)$ & TQ(5) & $\mathrm{TQ}(6)$ \\
\hline Constants & $\begin{array}{l}10.389 \text { *** } \\
(25.85)\end{array}$ & & & & & \\
\hline Ind & $\begin{array}{l}0.026^{* * *} \\
(0.56)\end{array}$ & & & & & \\
\hline Dep_cpa & & $\begin{array}{l}0.125^{* * *} \\
(3.13)\end{array}$ & & & & \\
\hline Dep_edu & & & $\begin{array}{c}0.176 * * * \\
(3.07)\end{array}$ & & & \\
\hline Number & & & & $\begin{array}{c}0.056 * * * \\
(9.26)\end{array}$ & & \\
\hline Regulation & & & & & $\begin{array}{c}0.032 \text { *** } \\
\quad(6.08)\end{array}$ & \\
\hline IA & & & & & & $\begin{array}{l}0.059 * * * \\
(3.62)\end{array}$ \\
\hline Big4 & $\begin{array}{r}0.102 \text { *** } \\
(3.92)\end{array}$ & $\begin{array}{c}0.103 * * * \\
(3.92)\end{array}$ & $\begin{array}{c}0.105 * * * \\
(3.95)\end{array}$ & $\begin{array}{r}0.009 * * * \\
(3.62)\end{array}$ & $\begin{array}{r}0.087 * * * \\
(3.35)\end{array}$ & $\begin{array}{r}0.100 * * * \\
(3.89)\end{array}$ \\
\hline Lev & $\begin{array}{r}0.793 \text { *** } \\
(8.35) \\
\end{array}$ & $\begin{array}{r}0.790 * * * \\
(8.34)\end{array}$ & $\begin{array}{r}0.792 * * * \\
(8.35)\end{array}$ & $\begin{array}{r}0.701 * * * \\
(7.73)\end{array}$ & $\begin{array}{r}0.819 * * * \\
(8.68)\end{array}$ & $\begin{array}{r}0.798 * * * \\
(8.42)\end{array}$ \\
\hline Lnsize & $\begin{array}{r}0.216^{* * *} \\
(4.52)\end{array}$ & $\begin{array}{r}0.216 * * * \\
(4.55)\end{array}$ & $\begin{array}{r}0.217 * * * \\
(4.62)\end{array}$ & $\begin{array}{r}0.179 * * * \\
(3.12)\end{array}$ & $\begin{array}{r}0.237^{* * *} \\
(4.72)\end{array}$ & $\begin{array}{r}0.231 * * * \\
(4.32)\end{array}$ \\
\hline Growth & $\begin{array}{r}0.029 * * * \\
(1.33) \\
\end{array}$ & $\begin{array}{r}0.028 * * * \\
(1.25)\end{array}$ & $\begin{array}{c}0.030 * * * \\
(1.37)\end{array}$ & $\begin{array}{r}0.021 * * * \\
(1.08)\end{array}$ & $\begin{array}{r}0.027^{* * *} \\
(1.31)\end{array}$ & $\begin{array}{r}0.028 * * * \\
(1.32)\end{array}$ \\
\hline Roa & $\begin{array}{r}6.331 \text { *** } \\
(18.62) \\
\end{array}$ & $\begin{array}{r}6.159 * * * \\
(18.12) \\
\end{array}$ & $\begin{array}{r}6.317 * * * \\
(18.13) \\
\end{array}$ & $\begin{array}{r}6.259 * * * \\
(18.23)\end{array}$ & $\begin{array}{r}6.259 * * * \\
(18.81)\end{array}$ & $\begin{array}{r}6.279 * * * \\
(18.73)\end{array}$ \\
\hline Share & $\begin{array}{r}0.005^{* * *} \\
(0.87)\end{array}$ & $\begin{array}{r}0.005 * * * \\
(0.82)\end{array}$ & $\begin{array}{c}0.004 * * * \\
(0.79)\end{array}$ & $\begin{array}{r}0.008 * * * \\
(0.96)\end{array}$ & $\begin{array}{r}0.005 * * * \\
(0.81)\end{array}$ & $\begin{array}{r}0.006 * * * \\
(0.92)\end{array}$ \\
\hline BoardSize & $\begin{array}{r}0.087 \text { *** } \\
(0.72)\end{array}$ & $\begin{array}{r}0.091 * * * \\
(0.75)\end{array}$ & $\begin{array}{r}0.095 * * * \\
(0.75)\end{array}$ & $\begin{array}{r}0.051 * * * \\
(1.12)\end{array}$ & $\begin{array}{r}0.088 * * * \\
(0.76)\end{array}$ & $\begin{array}{r}0.089 * * * \\
(0.79)\end{array}$ \\
\hline $\mathrm{N}$ & \multicolumn{6}{|c|}{1258} \\
\hline $\mathrm{R}^{2}$ & \multicolumn{6}{|c|}{0.363} \\
\hline
\end{tabular}

Note: Due to a limit of space, dummy variables are branched into CONTROL instead of being listed separately. ${ }^{* * *}$ refers to the significance level of 0.01 while $* *$ indicates the significance level of 0.05 . $\mathrm{T}$ value is given in parenthesis. The following tables are the same.

2. The testing of hypothesis H2. The analysis in Table 2 tells that when Chairman and CEO pay relatively much attention to internal audit quality, IA is significantly associated with TQ, and vice versa. The internal audit quality and management structure are interchanged in the sample and analyzed by regression. Judging from the result (column TQ $\langle 1\rangle$ and TQ $\langle 2\rangle$ ), it is clear that the coefficient of interaction terms is positive, which indicates that a favorable interaction of management structure plays an active role to improve corporate value. Thus Hypothesis $\mathrm{H} 2$ is verified. 
Table 2 Multivariable Regression Analysis of Internal Audit Quality, Interactive Mechanism of Management Structure and Corporate Value

\begin{tabular}{|c|c|c|c|c|c|c|}
\hline Variables & $\begin{array}{c}\text { TQ(1-1) } \\
\text { ChairAtt=1 }\end{array}$ & $\begin{array}{c}\text { TQ(1-2) } \\
\text { ChairAtt }=0\end{array}$ & $\begin{array}{c}\text { TQ (1) } \\
\text { ChairAtt=1,0 }\end{array}$ & $\begin{array}{l}\text { TQ(2-1) } \\
\text { CEOAtt=1 }\end{array}$ & $\begin{array}{c}\text { TQ(2-2) } \\
\text { CEOAtt }=0\end{array}$ & $\begin{array}{c}\text { TQ (2) } \\
\text { CEOAtt=1, } 0\end{array}$ \\
\hline IA & $\begin{array}{c}0.063 * * \\
(3.92)\end{array}$ & $\begin{array}{c}-0.103 * * * \\
(-1.23) \\
\end{array}$ & $\begin{array}{c}-0.058 * * \\
(-2.37)\end{array}$ & $\begin{array}{c}0.056 * * * \\
(3.52)\end{array}$ & $\begin{array}{c}-0.03 * * * \\
(-0.17)\end{array}$ & $\begin{array}{c}-0.103 * * * \\
(-0.32) \\
\end{array}$ \\
\hline ChairAtt & & & $\begin{array}{l}-0.046 * \\
(-1.55)\end{array}$ & & & \\
\hline ChairAtt*IA & & & $\begin{array}{c}0.165 * * * \\
(4.33)\end{array}$ & & & \\
\hline CEOAtt & & & & & & $\begin{array}{c}-0.076 * * \\
(-1.95)\end{array}$ \\
\hline CEOAtt*IA & & & & & & $\begin{array}{c}0.086 * * \\
(1.87)\end{array}$ \\
\hline $\mathrm{N}$ & \multicolumn{6}{|c|}{1258} \\
\hline $\mathrm{R}^{2}$ & \multicolumn{6}{|c|}{0.363} \\
\hline
\end{tabular}

(3) Robustness Test

To enhance the reliability of the result, this paper removes the possible endogenous problems in internal audit quality and corporate value for further testing, and the result remains the same as previous one. Meanwhile, to make the research more exact, the completeness of the sample is abandoned to increase the amount of samples. After a new round of selection and regression analysis of the samples, the result remains the same as previous one.

\section{Conclusion}

To sum up, the enlightenment are as follows. Firstly, the increase of internal audit quality helps to elevate company performance and add corporate value. Secondly, a favorable interaction of management structure has positive mediating effect on corporate value. Thirdly, company is suggested to improve the management structure and promote value-added service of internal audit. Fourthly, company should consolidate internal audit structure by enhancing the independence, improving professional quality of auditors, optimizing internal audit system and reinforcing the quality, which will bring the value-added function of internal audit into full play.

\section{Reference}

[1]Bing Wang, Liyun Liu, Demand Survey and Development Strategy of China Internal Audit [J]. Auditing Research, 2015(2):73-94

[2]Chun Cai, Li Cai, Qiurong Tian. The Function of Internal Audit and Corporate Value [J]. China Accounting Review, 2011(3):283-300

[3]Ying Chen, Bin Lin. Internal Audit, Interaction of Management System and Corporate Value [J]. Auditing Research, 2016(1):101-107

[4]Singh, H, Newby, R. Internal Audit and Audit Fees: Further Evidence [J]. Managerial Auditing Journal, 2010,25(4) 
[5]Shiying Huang, Wenfang Wu, Kejing Chen. The Influence of Corporate Management and CPA Audit on Earnings Quality [J]. Journal of Nanjing Audit University, 2012(2):87-95 